\title{
Lobaria pulmonaria (L.) Hoffm. in the southwestern Baltic - Kattegat area
}

\section{Ulf Schiefelbein $^{1}$, Terkel Arnfred ${ }^{2}$, Christian Dolnik ${ }^{3}$, Patrick Neumann ${ }^{4}$, Emilia Ossowska ${ }^{5}$, Roar Poulsen ${ }^{5}$, Ulrik Søchting ${ }^{6}$, Arne Thell ${ }^{7}$}

${ }^{1}$ Rostock University, Botanical Garden, Schwaansche Straße 2, 18055 Rostock, Germany.

E-mail: ulf.schiefelbein@uni-rostock.de

${ }^{2}$ Mågevej 26, 9000 Aalborg, Denmark. E-mail: terkel.arnfred@get2net.dk

\author{
${ }^{3}$ Kiel University, Institute for Natural Resource Conservation, Department of Landscape Ecology, Olshausenstr. 75, \\ D-24118 Kiel, Germany. E-mail: cdolnik@ecology.uni-kiel.de \\ ${ }^{4}$ Erna-Zöller-Str. 13, 24582 Bordesholm, Germany. E-mail: p.neumann@ecology-sh.de \\ ${ }^{5}$ Department of Plant Taxonomy and Nature Conservation, Faculty of Biology, University of Gdansk, Wita Stwosza 59, \\ PL-80-308 Gdansk, Poland. E-mail: emilia.ossowska@ug.edu.pl \\ ${ }^{5}$ Smallegade 2, 9520 Skørping, Denmark. E-mail: rsp231271@gmail.com \\ ${ }^{6}$ University of Copenhagen, Department of Biology, Section for Ecology and Evolution, Universitetsparken 15, \\ DK-2100 Copenhagen Ø, Denmark. E-mail: ulriks@bio.ku.dk \\ ${ }^{7}$ Lund University, Biological Museum, Botanical Collections, Box 117, SE-22100 Lund, Sweden. \\ E-mail: arne.thell@biol.lu.se
}

\begin{abstract}
The past and present distribution of Lobaria pulmonaria in Denmark, northern Germany, northwestern Poland and nemoral parts of Skåne, Blekinge, southwesternmost Småland and southern Öland (Sweden) has been studied. Of 124 localities visited between 2015 and 2018, L. pulmonaria was confirmed at 64 sites, at each of which its habitat ecology and viability were investigated. It is almost extinct in Schleswig-Holstein, in southern Jutland, on the Danish Islands, in southwestern Skåne, in Mecklenburg-Vorpommern and in the western part of Pomerania. It has disappeared almost completely from areas where mesophytic forests form the potential natural vegetation. The commonest habitats for L. pulmonaria are species-poor acidic beech and species-poor oak forests, and the commonest substrates are trunks of beech, followed by oak. L. pulmonaria specimens on about two thirds of the colonized trees were in a healthy condition. The situation is worst in Schleswig-Holstein and on the Danish Islands, but best in Blekinge and central and northern Jutland. Recent distribution seems to be influenced by both anthropogenic (e.g. air pollution by sulphur dioxide and nitrogen and forestry practices) and natural factors (precipitation, temperature, air humidity), as well as unnatural climatic factors (global warming).
\end{abstract}

Keywords: historical and recent distribution, habitats, ecology, viability

\section{INTRODUCTION}

The lungwort lichen, Lobaria pulmonaria (L.) Hoffm., is one of the most conspicuous lichens having a characteristic morphology; therefore, it is frequently observed also by non-lichenologists. Many advanced studies have been undertaken to understand its distribution and ecology (e.g. Wirth, 1968; Farmer et al., 1991; Rose, 1992; Gauslaa \& Solhaug, 1999; Wolseley \& James, 2000; Edman et al., 2008; Jüriado \& Liira, 2009; Jüriado et al., 2011; Gauslaa et al., 2017, 2020; Beckett et al., 2019; Jüriado \& Paal, 2019; Phinney et al., 2019), but there is still a lack of knowledge that explains its ecological and climatic requirements, since it occurs in a wide range of environments. Lobaria pulmonaria is widely distributed in the northern hemisphere (Litterski, 1999; Brodo et al., 2001; Jørgensen \&
Tønsberg, 2007; Urbanavichus \& Andreev, 2010; Widmer et al., 2012; Grimm et al., 2021), but has decreased remarkably since the 19th century, becoming rare and threatened in, for example, the Central European lowland (Diederich \& Sérusiaux, 2000; Cieśliński et al., 2006; Aptroot et al., 2011; Wirth et al., 2011), and southernmost Scandinavia (Hallingbäck, 1986; Hallingbäck \& Olsson, 1987; Jørgensen \& Tønsberg, 2007; Schiefelbein et al., 2016, 2017; Schiefelbein \& Thell, 2018; Thell \& Schiefelbein, 2018). In this study we follow the changes in its distribution and frequency in the southwestern Baltic and Kattegat area over different time periods since the mid-19th century. Earlier studies have shown that it suffered a decline for a long time, mainly due to agriculture, intensive forestry and emissions (e.g. Farmer et al., 1992; Gustafsson 
et al., 1992; Farmer, 1997; Wolseley \& James, 2000; Pykäla, 2004; Seaward \& Coppins, 2004; Kalwij et al., 2005; Edman et al., 2008; Jüriado $\&$ Liira, 2010; Schiefelbein \& Thell, 2018). However, it still occurs in places where it is difficult to explain its existence, such as in those close to intensive agricultural activities. Four questions were formulated: (1) where did L. pulmonaria grow in the southwestern Baltic area in the past, (2) where is it still present, (3) in which habitats is it still present, and (4) how healthy is it? To answer these questions, literature, herbaria and databases were consulted, as well as the actual localities where it occurred in the recent past. The answers to these questions can help with a successful long-term conservation of $L$. pulmonaria. Some results of this study in Sweden have already been published (Schiefelbein et al., 2016, 2017; Schiefelbein \& Thell, 2018; Thell \& Schiefelbein, 2018).

\section{MATERIAL AND METHODS}

\section{Study area}

The study area in the southwestern Baltic Sea and Kattegat area covers Denmark, the nemoral zone of Sweden including most of Skåne, coastal regions of Bohuslän, Halland, Blekinge, the southernmost Kalmar region and the southern part of Öland, northwestern Poland including the voivodeship Western Pomerania, Pomerania and adjacent regions, and northern Germany including the federal states Mecklenburg-Vorpommern and Schleswig-Holstein. The study area has been divided into eight geographical regions (Fig. 1): central and northern Jutland (J), Danish Islands incl. Bornholm (DI), coastal region along Kattegat (Halland, Bohuslän; BH), Skåne (Sk), coastal region of Blekinge and southernmost Kalmar (BK), Pomerania and Kashubia (Pom), MecklenburgWestern Pomerania incl. Wolin island $(\mathrm{M}-\mathrm{V})$

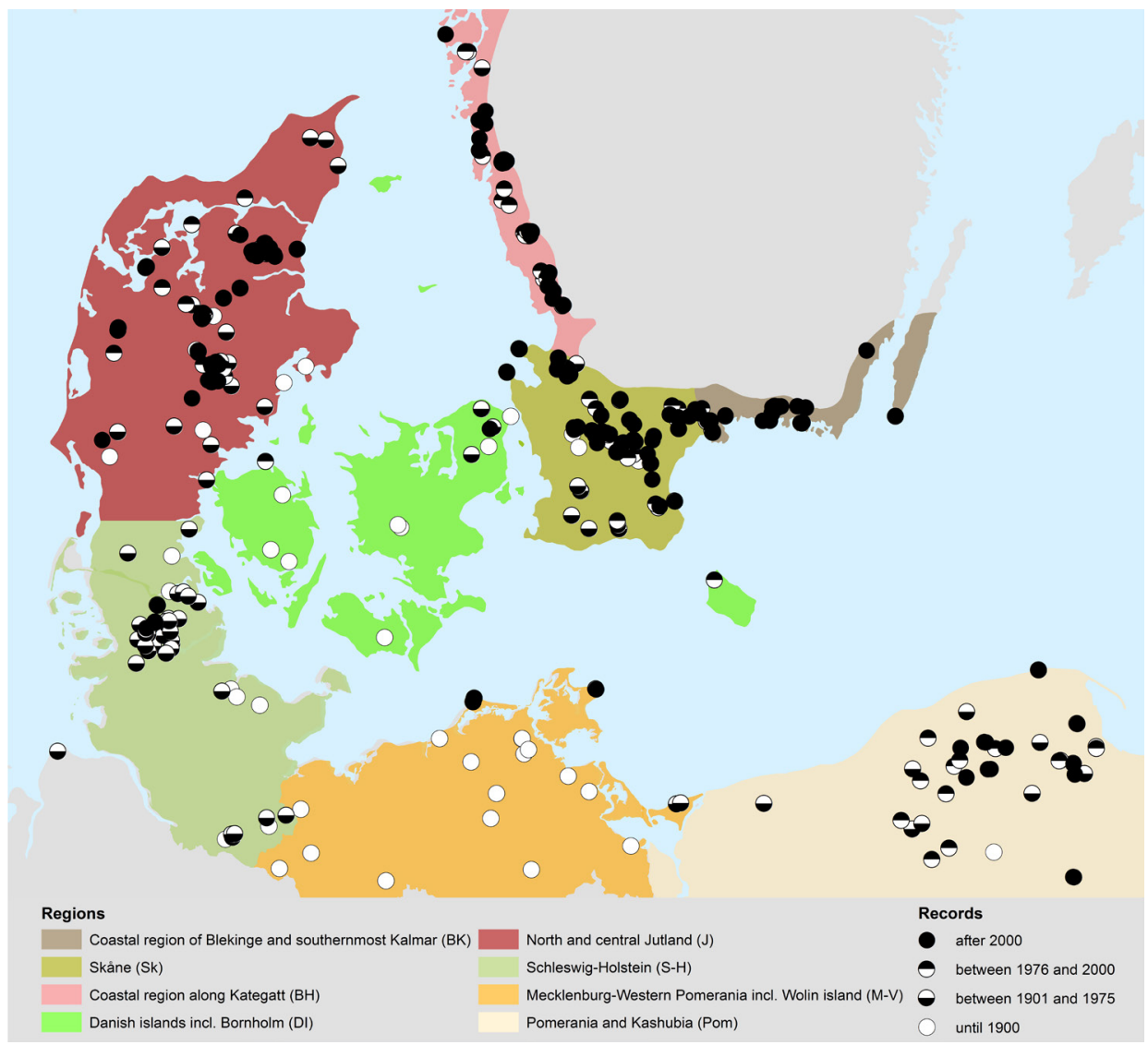

Fig. 1. Distribution of Lobaria pulmonaria in the studied regions of Denmark, Sweden, Germany and Poland. 
and Schleswig-Holstein including also northern Schleswig, which is a part of Denmark $(\mathrm{S}-\mathrm{H})$.

The study area is actually predominated by agricultural landscapes. Large forested areas only occur in Poland and Mecklenburg-Vorpommern on terminal moraines and in nutrient poor sand areas, as well as in Sweden at the northern edge of the study area and in the transition to the boreal vegetation zone (Fig. 2). The natural vegetation of the study area would have been mainly mesophytic species-rich beech, speciespoor acidic beech, species-poor oak, and mixed oak-hornbeam forests (Bohn \& Neuhäusl, $2000 / 2003)$. In addition, alluvial and wet lowland forests would have been distributed in the Elbe river valley and along the North Sea coast of Schleswig-Holstein, at swamps and fen forests in river valleys, non-forest coastal vegetation and some raised bogs (Bohn \& Neuhäusl,
2000/2003). The distribution of the different potential natural vegetation types can be seen in Fig. $2 \& 4$.

The climate is temperate and characterized by moderate temperatures. The average annual temperature ranges from 5.6 to $9.0^{\circ} \mathrm{C}$, and the average annual precipitation from 480 to 1060 mm (Fick \& Hijmans, 2017). Regions with lower average annual temperatures are in Pomerania, in central Skåne and at the border to the boreal vegetation zone.

\section{Compilation of distribution data}

For historical and recent records, the databases Danmarks svampeatlas (www.svampeatlas. $\mathrm{dk}$ ), Artportalen (www.artportalen.se) and Sweden's Virtual Herbarium (www.herbarium. emg.umu.se) were consulted, as well as literature sources (Krawiec, 1933; Saxen, 1963;

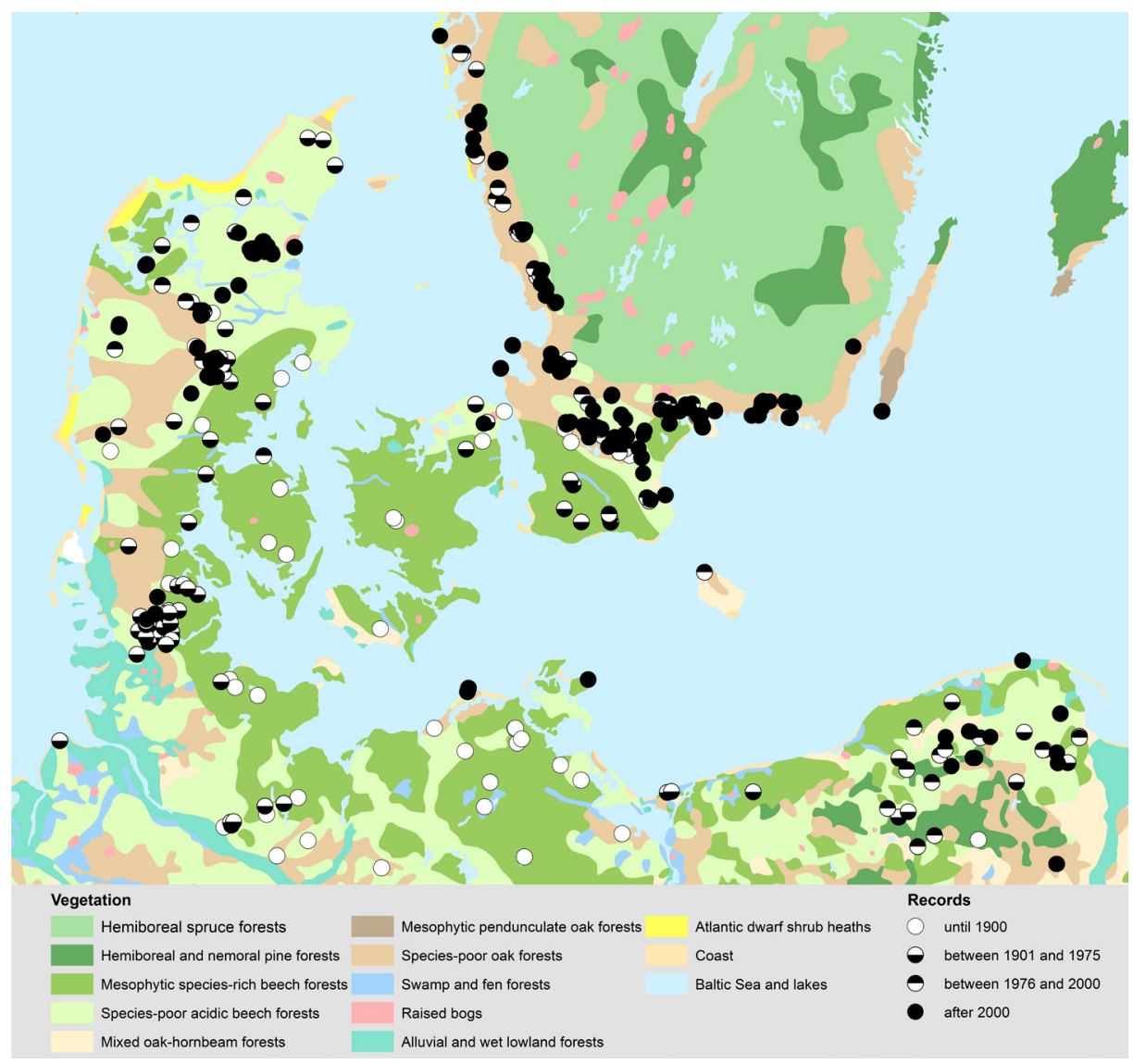

Fig. 2. Distribution of Lobaria pulmonaria in the study area and potential natural vegetation according to Bohn \& Neuhäusl (2000/2003). 
Izydorek, 1987; Søchting \& Christensen, 1989; Fałtynowicz, 1992; Christensen \& Søchting, 1996; Fałtynowicz \& Kukwa, 2000; Fałtynowicz et al., 2000; Dolnik, 2004; Schiefelbein et al., 2016, 2017; Schiefelbein \& Thell, 2018; Thell \& Schiefelbein, 2018; Neumann \& Dolnik, 2018). Some Polish records were personally communicated by W. Fałtynowicz (Wrocław), A. Ryś (Strzałowo) and M. Kukwa (Gdansk). The records were divided into four time periods: 19th century including 1900, 1901-1975, 1976-2000, and 2001 onwards.

\section{Inventory work in 2015-2018}

Between 2015 and 2018, 124 localities of $L$. pulmonaria were visited; in Denmark and Germany only localities that were recently known at the beginning of the study, in Sweden, all sites reported to Artportalen in Skåne, southern Blekinge and southern Kalmar region since 1990, except for few difficult to reach remote sites, and in Poland, those sites recorded in the 1980s by Izydorek (1987) and those after 1990 personally communicated by W. Fałtynowicz, A. Ryś and M. Kukwa.

These studies were carried out as a part of an on-going population genetic study. Therefore, the main goal was not to check all known recent and historical localities, but to find as many specimens as possible. The species was searched for not only at the original locality, but also in suitable surroundings. The size of the study area at the localities depended on the accuracy of the information. The more precise information, the smaller area examined.

For those trees with L. pulmonaria, the habitat type, the host tree species and viability of the population on the host tree were determined. The habitats are classified into six classes: species-poor oak forests, species-poor acidic beech forests, mesophytic species-rich beech forests, Tilio-Acerion forests, mixed oak-hornbeam forests or wooded meadows. Four classes of viability of the population on the host tree have been distinguished: (1) specimens of populations with poor viability were strongly damaged; there were no young thalli, populations were of few small specimens; (2) specimens of populations with moderate viability were with partly damaged specimens or lobes, respectively; healthy lobes were only few at the edge of the thalli and younger thalli were almost absent; (3) specimens of population of good viability bore isidia, phyllidia or soredia in abundance; most thalli looked healthy, younger thalli were usually present; (4) population with specimens bearing apothecia on the thalli were considered to be of very good viability.

\section{RESULTS}

\section{Historical and recent distribution of Lobaria pulmonaria in the study area}

As a result of the inventory, 332 historical and/ or recent localities could be identified in the study area. The number of records in the different regions and periods can be seen in Table 1. The localities are spread over the whole area and occur in almost all parts of the study area (Figs $1 \& 2$ ). Most localities are in central and northern Jutland and in Skåne, and least in Mecklenburg-Vorpommern and on the Danish Islands. According to the famous Danish botanist Emil Rostrup, L. pulmonaria occurred here and there on beeches on Lolland in the mid-19th century (Rostrup, 1864), but no other reports or collections are known from the southern Danish Islands. The number of localities in the Blekinge/Kalmar region is also very low, but this region is very small.

Regarding the number of localities since 2000, the situation is similar, the only difference being that the number of localities in SchleswigHolstein were reduced to three. The proportion of the recent localities out of total known localities is high in central and northern Jutland, all Swedish regions and in Pomerania. In contrast, the percentage of recent localities of all known ones is low in the German regions and on the Danish Islands.

There has been a significant shrinkage in the distribution of L. pulmonaria. It has disappeared almost completely in Schleswig-Holstein, on the Danish Islands, in southwestern Skåne, in Mecklenburg-Vorpommern and in the western part of Pomerania (Fig. 1, Table 1). The only recent localities in these regions are in the Old Drift landscape (Geest) of Schleswig-Holstein, on the northern coast of Rügen, the Darß-Zingst Peninsula in Mecklenburg-Vorpommern, and in northern Zealand where it became extinct in 2015. In central and northern Jutland, it occurs almost exclusively in the centrally located 
large forest complexes and in coastal regions. In Pomerania, the current area reaches from Słupsk in the west to Kashubia (west of Gdansk) in the east. The localities in Bohuslän/Halland, northern and eastern Skåne, Blekinge and the Kalmar region declined in the past, but a reduction of the distribution area is not recognizable.

The localities of L. pulmonaria are mainly in areas where the potential natural vegetation are oak and beech forests (Figs $2 \& 3$ ). Only few localities are in areas with other potential vegetation types, 6 in nemoral pine forests, 4 in alluvial and wet lowland forests, and 2 in raised bogs. The percentages of records between mesophytic (mesophytic species-rich beech forests, mixed oak-hornbeam forests, mesophytic pedunculate oak forests) and acidic forest types (species-poor acidic beech forest, species-poor oak forests) have changed over time (Fig. 3). Before 1900, most records were in areas with potentially mesophytic forests. Since then, the percentage of records in mesophytic forests has continuously declined; today, only 10 localities are located in areas of these forest types, 4 in Skåne, 4 in Blekinge/Kalmar, 1 in Pomerania and 1 in Mecklenburg-Vorpommern.

Table 1. Number of records in the different regions and periods. Abbreviations: $\mathrm{J}$ - central and northern Jutland, DI - Danish Islands incl. Bornholm, BH - coastal region along Kattegat (Halland, Bohuslän), Sk - Skåne, BK - coastal region of Blekinge and southernmost Kalmar, Pom - Pomerania and Kashubia, M-V - Mecklenburg-Western Pomerania incl. Wolin island, $\mathrm{S}-\mathrm{H}$ - Schleswig-Holstein including also northern Schleswig.

\begin{tabular}{llllllllll}
\hline $\begin{array}{l}\text { Time } \\
\text { period }\end{array}$ & \multicolumn{10}{c}{ Number of records } \\
\cline { 2 - 10 } & J & DI & BH & Sk & BK & Pom & M-V & S-H & Total \\
\hline$\leq 1900$ & 8 & 8 & 0 & 6 & 0 & 1 & 16 & 6 & 45 \\
$1901-1975$ & 26 & 3 & 2 & 12 & 0 & 13 & 3 & 35 & 94 \\
$1976-2000$ & 34 & 2 & 32 & 48 & 7 & 12 & 2 & 2 & 139 \\
$>2000$ & 30 & 1 & 19 & 41 & 21 & 11 & 3 & 3 & 129 \\
Total & 79 & 13 & 40 & 81 & 21 & 35 & 21 & 42 & 332 \\
\hline
\end{tabular}

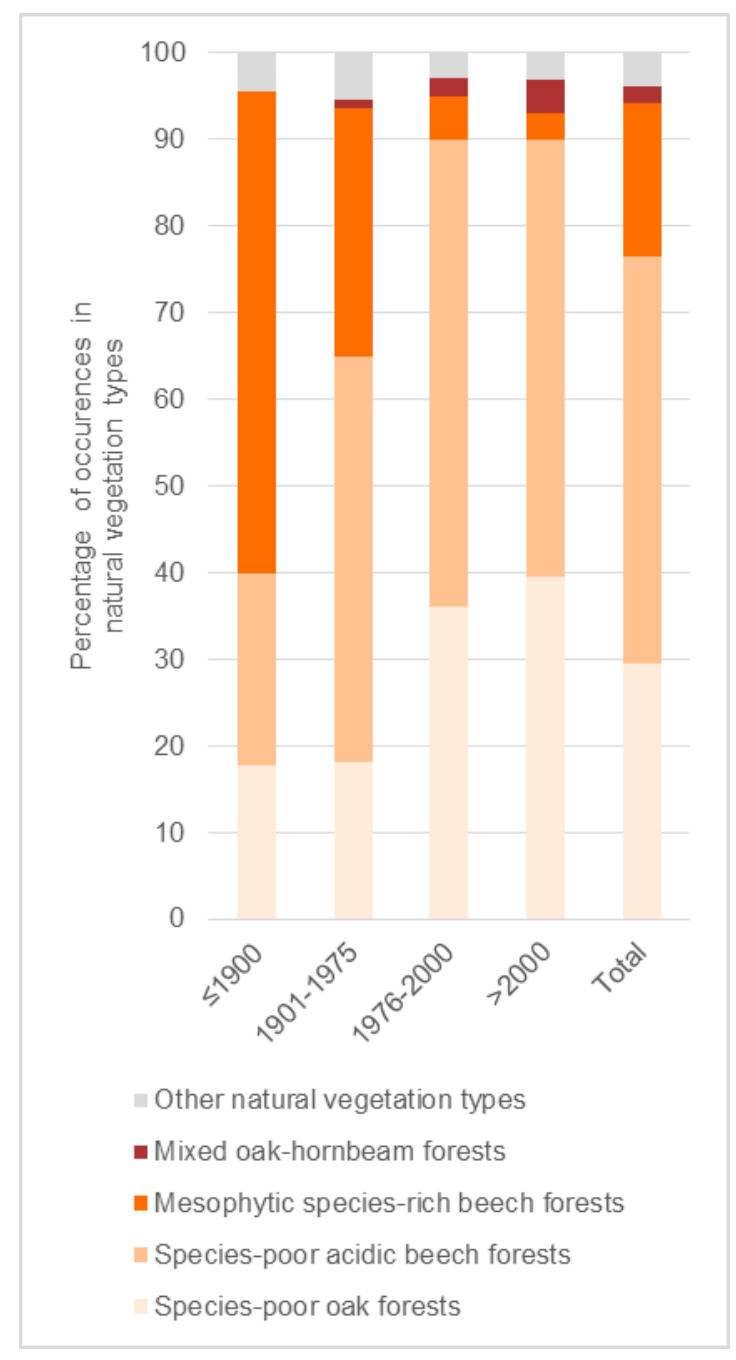

Fig. 3. Percentage of the localities in different potential natural vegetation types according to Bohn \& Neuhäusl (2000/2003).

Inventory work in 2015-2018 - Between 2015 and 2018, the occurrence of L. pulmonaria could be confirmed at 64 localities (see Appendix 1) of the 124 visited localities (Fig. 4). At these localities, 150 trees inhabited by L. pulmonaria were found, but the search ceased at most localities after five trees with L. pulmonaria had been discovered. 


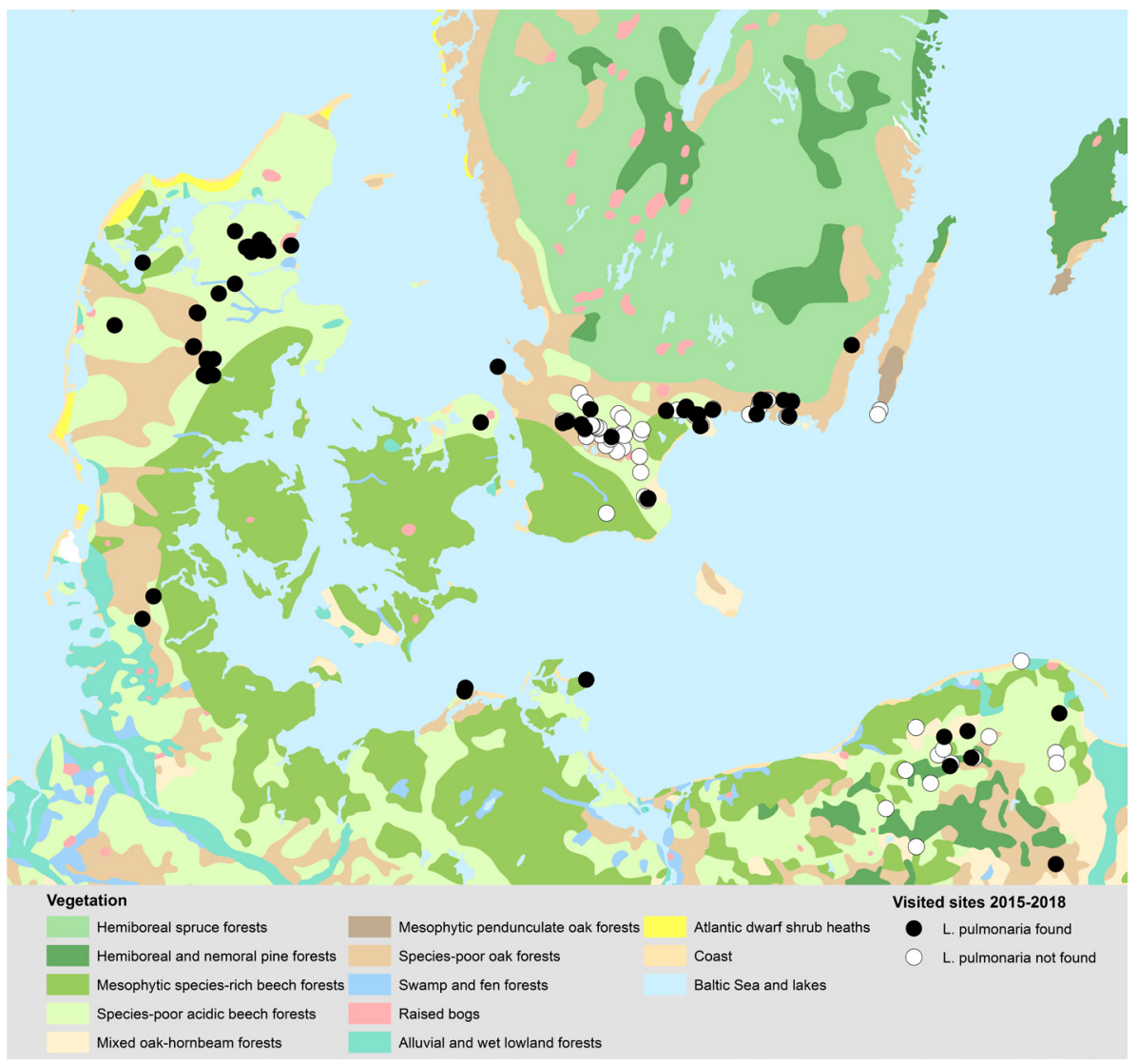

Fig. 4. Studied localities between 2015 and 2018 and potential natural vegetation according to Bohn \& Neuhäusl (2000/2003).

Table 2. Number of visited localities and studied trees with Lobaria pulmonaria in habitat categories. (For abbreviations, see Table 1)

\begin{tabular}{lllllllll}
\hline Vegetation type & \multicolumn{3}{l}{ Number of localities/trees } & & & \\
\cline { 2 - 8 } & $\mathrm{J}$ & $\mathrm{DI}$ & $\mathrm{Sk}$ & $\mathrm{BK}$ & $\mathrm{Pom}$ & $\mathrm{M}-\mathrm{V}$ & $\mathrm{S}-\mathrm{H}$ & Total \\
\hline Species-poor oak forests & $7 / 29$ & 0 & 0 & 0 & $2 / 2$ & 0 & $1 / 2$ & $10 / 33$ \\
Species-poor acidic beech forests & $19 / 60$ & $1 / 1$ & $6 / 7$ & $6 / 8$ & $3 / 3$ & $2 / 5$ & 0 & $37 / 84$ \\
Mesophytic species-rich beech forests & $1 / 1$ & 0 & $1 / 3$ & $1 / 3$ & 0 & $1 / 1$ & 0 & $4 / 8$ \\
Tilio-Acerion forests & 0 & 0 & $4 / 9$ & $3 / 9$ & $1 / 2$ & 0 & 0 & $8 / 20$ \\
Mixed oak-hornbeam forests & 0 & 0 & $1 / 1$ & $1 / 1$ & 0 & 0 & $1 / 1$ & $3 / 3$ \\
Wooded meadow; meadow with trees & 0 & 0 & 0 & $2 / 2$ & 0 & 0 & 0 & $2 / 2$ \\
Total & $27 / 90$ & $1 / 1$ & $12 / 20$ & $13 / 23$ & $6 / 7$ & $3 / 6$ & $2 / 3$ & $64 / 150$ \\
\hline
\end{tabular}

Sixty-two (of 64) investigated localities and 148 (of 150) host trees are located in forests; only two localities and two host trees are in wooded meadows. 46 localities and 117 host trees occurred in species-poor acidic forests (species-poor acidic beech forests, species-poor oak forests) and 15 localities and 31 host trees in mesophytic forests (mesophytic species-rich beech forests, lime-maple forests, mixed oakhornbeam forests; Table 2). 
Table 3. Number of studied occurrences of Lobaria pulmonaria on different host tree species. (For abbreviations, see Table 1)

\begin{tabular}{lllllllll}
\hline \multirow{2}{*}{ Tree species } & \multicolumn{3}{l}{ Number of records } & & & & Total \\
\cline { 2 - 8 } & J & DI & Sk & BK & Pom & M-V & S-H & \\
\hline Acer platanoides & 0 & 0 & 6 & 7 & 1 & 0 & 0 & 14 \\
Carpinus betulus & 0 & 0 & 0 & 1 & 0 & 0 & 0 & 1 \\
Fagus sylvatica & 61 & 1 & 8 & 5 & 3 & 6 & 0 & 84 \\
F. excelsior & 0 & 0 & 1 & 3 & 0 & 0 & 0 & 4 \\
Quercus spec. & 29 & 0 & 5 & 4 & 2 & 0 & 3 & 43 \\
Tilia cordata & 0 & 0 & 0 & 3 & 1 & 0 & 0 & 4 \\
Total & 90 & 1 & 20 & 23 & 7 & 6 & 3 & 150 \\
\hline
\end{tabular}

Lobaria pulmonaria occurred in all regions except Schleswig-Holstein in species-poor acidic beech forests. Most localities in this forest type were found in central and northern Jutland (Table 2). The localities in oak forests with a species poor ground floor vegetation were mainly situated in the western part of the study area, whereas the localities in mixed oak-hornbeam forests and lime-maple forests were, with one exception, of each forest type, in the northwestern part of the study area. The only locality in mixed oak-hornbeam forests outside Sweden was in Schleswig-Holstein, and the single locality in lime-maple forests was in Pomerania. However, the basic conditions are different, as the localities in Sweden are in rocky places whereas the Pomeranian locality was entirely without stones. Localities on wooded meadows were exclusively found in Blekinge.

The most inhabited tree species in the study area was Fagus sylvatica, followed by Quercus species (mainly Q. robur), and Acer platanoides (Table 3); very few occurrences were on Fraxinius excelsior and Tilia cordata and only one on Carpinus betulus.

Lobaria pulmonaria specimens on about two thirds of the colonized trees were in a healthy condition, five of them even with apothecia (Fig. 5). The situation was less favourable in Schleswig-Holstein and on the Danish Islands where the few specimens found were in bad condition. At the locality on Zealand, c. $6 \mathrm{~km} \mathrm{NE}$ of Hillerød, Nødebo Holt (De 21), the only remaining L. pulmonaria had fallen to the ground and thus became extinct in eastern Denmark during this study. The situation was slightly more favourable in Mecklenburg-Vorpommern and

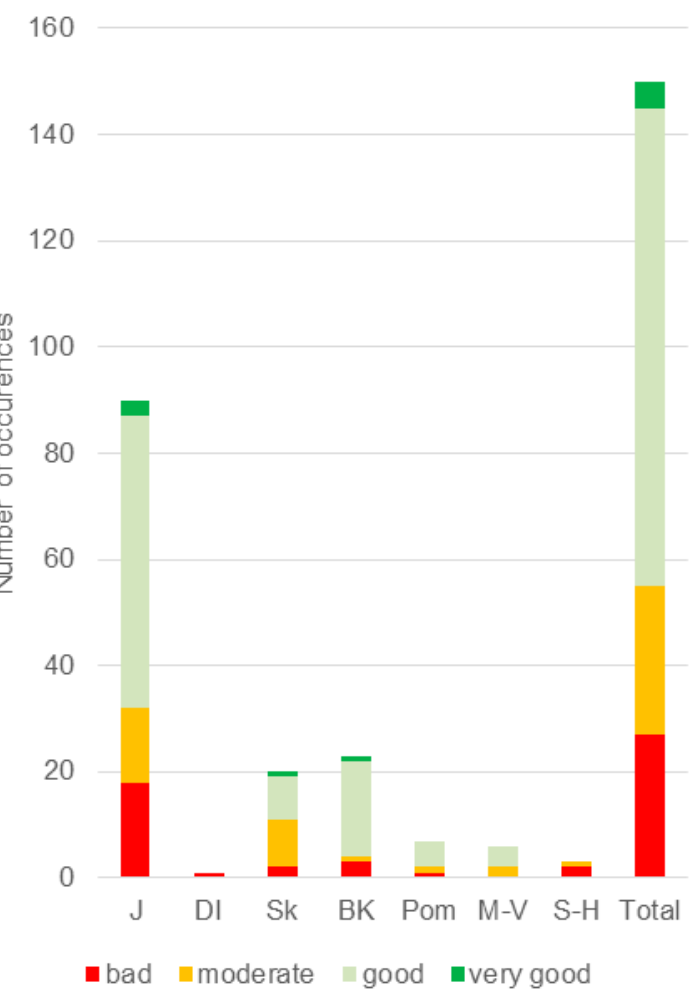

Fig. 5. Viability of Lobaria pulmonaria in the studied area.

Pomerania, because the number of colonized trees was slightly higher and the occurrences in good condition dominated. Even more colonized trees could be found in Skåne and Blekinge/ Kalmar, but the healthiest specimens were seen on trees in Blekinge. The best situation in 
respect of both the number of colonized trees and health condition of the specimens was in central and northern Jutland.

\section{DISCUSSION}

The findings by Schiefelbein \& Thell (2018) in southernmost Sweden can be applied to the whole southwestern Baltic - Kattegat area. Lobaria pulmonaria was formerly widespread in the study area but disappeared from many regions. Today, it is almost restricted to regions where forest communities on rather nutrient-poor soils naturally dominate. In regions, where eutrophic beech forests or mixed oak-hornbeam forests would form the natural vegetation cover, $L$. pulmonaria is almost absent. These regions are of greater interest to agriculture; consequently, forests in these regions are proportionally less represented and stronger affected by eutrophication (and hypertrophication in some cases) and atmospheric pollution (Schiefelbein \& Thell, 2018). Andersson \& Appelqvist (1987) also noted that L. pulmonaria had disappeared from the central part of their study area in SW Sweden due to the fact that this area was deforested for a long period which ended a century ago.

The major reasons for its decline are air pollution by sulphur dioxide (e. g. Hawksworth \& Rose, 1970; Hawksworth et al., 1973; Hallingbäck \& Olsson, 1987; Farmer et al., 1991; Gauslaa, 1995; Farmer, 1997), and later, nitrogen (e. g. Farmer, 1997; Wolseley \& James, 2000; Seaward \& Coppins, 2004, Hauck \& Wirth, 2010). In addition, forestry practices have strongly influenced L. pulmonaria in different respects over a long period of time (e. g. Wirth, 1968; Andersson \& Appelqvist, 1987; Gustafsson et al., 1992; Gauslaa \& Solhaug, 1996; Gu et al., 2001; Öckinger et al., 2005; Gauslaa et al., 2006, 2007; Edman et al., 2008; Gustafsson \& Milberg, 2008; Carlsson \& Nilsson, 2009; Johansson et al., 2007; Jüriado \& Liira, 2009, 2010; Öckinger \& Nilsson, 2010; Jüriado et al., 2011; Schiefelbein \& Thell, 2018).

In addition to the above-mentioned anthropogenic causes, climatic factors influence the distribution of $L$. pulmonaria. Eaton \& Ellis (2012) found a significant relationship between thallus growth measured for experimental forest microhabitats and macroclimatic variables (total precipitation and annual mean temperature). This relationship was validated through a comparison with L. pulmonaria's North American range for which projected growth rates were higher and lower where the species tended to be present and absent, respectively. In the study area, the natural climatic conditions seem to be more suitable for L. pulmonaria in some regions than in others. It cannot be justified by other reasons why most recent localities of $L$. pulmonaria are concentrated in central and northern Jutland and on the Scanian horsts, which run in the north-west to south-east direction, marking the south-west border of Fennoscandia, at the edge to the boreal vegetation zone and in Pomerania and why L. pulmonaria is absent today in most of Mecklenburg-Vorpommern and western part of Pomerania. However, the climatic data by Fick \& Hijmans (2017) show that the climate of these regions is rather different; for example, the annual mean temperature is rather low on the Scanian horsts, at the border to the hemiboreal zone and in Pomerania and rather high in the western part of central and northern Jutland, in Schleswig-Holstein and at the MecklenburgVorpommern coast. The lowest mean temperature in the warmest quarter is in central and northern Jutland, on the Scanian horsts, and in the eastern part of Pomerania. The regions with the highest mean annual precipitation, where $L$. pulmonaria was recently found, are in SchleswigHolstein, in the western part of central and northern Jutland, in Halland/Bohuslän and on the Scanian horsts. In Schleswig-Holstein, Bohuslän/Halland and in the western part of central and northern Jutland, the annual rainfall can reach up to $900 \mathrm{~mm}$ (Fick \& Hijmans, 2017). The most eastern part of central and northern Jutland, northeastern Skåne, Blekinge/Kalmar, Mecklenburg-Vorpommern and a large part of Pomerania are rather dry, but the mean precipitation in the warmest quarter in Pomerania is much higher than the other regions.

According to Gauslaa (2014), rain, dew, and humid air are drivers of morphology, function and spatial distribution in epiphytic lichens. Thus, it is clear that precipitation is very important for the distribution of L. pulmonaria, but it is not obvious to which amount in general and at what time the rainfall is necessary, and how the rainfall will be compensated if the required amount does not fall. Temperature and air humidity undoubtedly play important roles for Lobaria, 
but which temperatures are most suitable for $L$. pulmonaria during the year, in the driest and in the warmest periods in relation to air humidity and vice versa.

In coastal regions, the Baltic Sea provides rather humid air, but Pentecost (2020) assumes that sea water also influences Lobaria spp. sites. Lobaria pulmonaria tends to grow on trees with alkaline bark preferably growing in alkaline soils far from the coast. Thus, all parameters that makes the water more alkaline seem beneficial for L. pulmonaria.

Mention should also be made to the unnatural climatic conditions induced by global warming which impact upon lichens (e.g. van Herk et al. 2002, Aptroot \& van Herk, 2007, Ellis et al. 2007, 2014, Aptroot et al., 2021), and more specifically to Lobaria species (Rose \& Purvis, 2009).

Another aspect related to the distribution of $L$. pulmonaria is the land cover in the vicinity of the occurrences. Skagerberg (2011) already noted that the presence of $L$. pulmonaria, the size of its thalli and the height of the lichen patches on the trunks were positively influenced by habitat size and adversely affected by habitat exposure. During the inventory between 2015 and 2018, it was conspicuous that most occurrences in central and northern Jutland, MecklenburgVorpommern and Pomerania were in extensive forests or forest complexes. The explanation is that forests protect L. pulmonaria against sulphur dioxide, eutrophication/hypertrophication to a certain extent (Seaward \& Coppins, 2004). One remaining question is how large a forest must be to neutralize the emissions.

In conclusion, many natural and anthropogenic factors influence the recent distribution in the Baltic Sea - Kattegat area, but interaction between the factors is still little known and needs to be studied in more detail.

\section{ACKNOWLEDGEMENTS}

We are very grateful to M. R. D. Seaward (Bradford) for linguistic revisions and improvements to drafts, and to The Ove Almborn Foundation for financial support. We thank W. Fałtynowicz (Wrocław), A. Ryś (Strzałowo) and M. Kukwa (Gdansk) for the provision of data. Furthermore, we are also indebted to the Nature Conservation authorities in Mecklenburg-Vorpommern
(Nationalparkamt Vorpommern), Skåne (Länsstyrelsen, Söderåsen Nationalpark) and Poland (Regional Directorate for Environmental Protection in Gdansk) for permission to conduct the study in protected areas.

\section{REFERENCES}

Andersson, L. \& Appelqvist, T. 1987. Lunglav och almlav, indikatorer på värdefull lövskog. Svensk Botanisk Tidskrift 81(3): 185-194.

Aptroot, A. \& van Herk, C. M. 2007. Further evidence of the effects of global warming on lichens, particularly those with Trentepohlia phycobionts. Environmental Pollution 146(2): 293-298.

Aptroot, A., van Herk, K. [C. M.] \& Sparrius, L. 2011. Basisrapport voor de Rode Lijst Korstmossen. BLWG-rapport 12: 1-108.

Aptroot, A., Stapper, N. J., Košuthová, A. \& van Herk, K. [C. M.] (2021) Lichens as an indicator of climate and global change. In: Letcher, T. (ed.). Climate Change. 3rd Edition. Elsevier, Amsterdam: 483-497. https://doi.org/10.1016/B978-0-12821575-3.00023-2

Beckett, P., Solhaug, K. A., Gauslaa, Y. \& Minibayeva, F. 2019. Improved photoprotection in melanized lichens is a result of fungal solar radiation screening rather than photobiont acclimation. Lichenologist 51(5): 483-491. https://doi.org/10.1017/ S0024282919000276

Bohn, U. \& Neuhäusl, R., with contributions by Gollub, G., Hettwer, C., Neuhäuslová, Z., Raus, Th., Schlüter, H. \& Weber, H. (2000/2003). Map of the Natural Vegetation of Europe. Scale 1:2 500000. Landwirtschaftsverlag, Münster.

Brodo, I. M., Sharnoff, S. D. \& Sharnoff. S. 2001. Lichens of North America. Yale University Press, New Haven and London. 795 pp.

Carlsson, R. \& Nilsson, K. 2009. Status of the red-listed lichen Lobaria pulmonaria on the Åland Islands, SW Finland. Annales Botanici Fennici 46: 549-554. https://doi.org/10.5735/085.046.0607

Christensen, S. N. \& Søchting, U. 1996. Overvågning af lungelav $i$ danske naturskove 1989. - Miljø og Energiministeriet, Skov og Naturstyrelsen, København, 39 pp.

Cieśliński, S., Czyżewska, K. \& Fabiszewski J. 2006. Red list of the lichens in Poland. In: Mirek, Z., Zarzycki, K., Wojewoda, W. \& Szelag, Z. (eds). Red List of Plants and Fungi in Poland. W. Szafer Institute of Biology, PAS, Kraków: 71-90.

Diederich, P. \& Sérusiaux, E. 2000. The Lichens and Lichenicolous Fungi of Belgium and Luxembourg. An Annotated Checklist. Musée National d'Histoire Naturelle, Luxembourg. 207 pp.

Dolnik, C. 2004. Überprüfung des Bestandes der in Schleswig-Holstein vom Aussterben bedrohten Arten Kurzhängendes Gegenzahnmoos (Antitrichia curtipendula) und Lungenflechte (Lobaria pulmonaria) im Pobüller Bauernholz. 
Abschlussbericht. AG Geobotanik in SchleswigHolstein und Hamburg, 8 pp +1 map.

Eaton, S. \& Ellis, C. J. 2012. Local experimental growth rates respond to macroclimate for the lichen epiphyte Lobaria pulmonaria. Plant Ecology and Diversity 5(3): 365-372.

Edman, M., Eriksson, A.-M. \& Villard, M.-A. 2008. Effects of selection cutting on the abundance and fertility of indicator lichens Lobaria pulmonaria and L. quercizans. Journal of Applied Ecology 45: 26-33. https: / /doi.org/10.1111/j.13652664.2007.01354.x

Ellis, C. J, Coppins, B. J., Dawson, T. P. \& Seaward, M. R. D. 2007. Response of British lichens to climate change scenarios: trends and uncertainties in the projected impact for contrasting biogeographic groups. Biological Conservation 140: 217-235.

Ellis, C. J., Eaton, S., Theodoropoulos, M., Coppins, B. J. \& Seaward, M. R. D. 2014. Response of epiphytic lichens to 21 st century climate change and tree disease scenarios. Biological Conservation 180: 153-164.

Faltynowicz, W. 1992. The lichens of Western Pomerania (NW Poland). An ecogeographical study. Polish Botanical Studies 4: 1-182.

Fałtynowicz, W. \& Kukwa, M. 2000. Lichens of the 'Cisy w Czarnem' reserve (western Pomerania, $\mathrm{N}$ Poland) with emphasis on old growth forest species. Folia Cryptogamica Estonica 36: 11-15.

Fałtynowicz, W., Marcinowska, E. \& Rutkowski, P. 2000. Lichens of the nature reserve "Dolina Zagórskiej Strugi” near Rumia in Kaszubskie Lake District. Acta Botanica Cassubica 1: 119-126.

Farmer, A. M. 1997. Impact of air pollution on Lobaria species. British Lichen Society Bulletin 80: 25-26.

Farmer, A. M., Bates, J. W. \& Bell, J. N. B. 1991. Comparisons of three woodland sites in NW Britain differing in richness of the epiphytic Lobarion pulmonariae community and levels of wet acidic deposition. Holarctic Ecology 19(2): 85-91. https://doi.org/10.1111/j.1600-0587.1991. tb00637.x

Farmer, A. M., Bates, J. W. \& Bell, J. N. B. 1992. The transplantation of four species of Lobaria lichens to demonstrate a field acid rain effect. Studies in Environmental Science 50(C): 295-300. https:// doi.org/10.1016/S0166-1116(08)70124-9

Fick, S. E. \& Hijmans, R. J. 2017. Worldclim 2: New 1-km spatial resolution climate surfaces for global land areas. International Journal of Climatology 37(1) 4302-4315. https://doi.org/10.1002/ joc. 5086

Gauslaa, Y. 1995. The Lobarion, an epiphytic community of ancient forests threatened by acid rain. $\mathrm{Li}$ chenologist 27: 59-76. https://doi.org/10.1017/ S0024282995000077

Gauslaa, Y. 2014. Rain, dew, and humid air as drivers of morphology, function and spatial distribution in epiphytic lichens. Lichenologist 46(1): 1-16. https://doi.org/10.1017/S0024282913000753
Gauslaa, Y., Goward, T. \& Pypker, T. 2020. Canopy settings shape elemental composition of the epiphytic lichen Lobaria pulmonaria in unmanaged conifer forests. Ecological Indicators 113, https:// doi.org/10.1016/j.ecolind.2020.106294

Gauslaa, Y., Lie, M., Solhaug, K. A. \& Ohlson, M. 2006. Growth and ecophysiological acclimation of the foliose lichen Lobaria pulmonaria in forests with contrasting light climates. Oecologia 147: 406-416. https://doi.org/10.1007/s00442-0050283-1

Gauslaa, Y., Palmqvist, K., Solhaug, K. A., Holien, H., Hilmo, O., Nybakken, L., Myhre, L. C. \& Ohlson, M. 2007. Growth of epiphytic old forest lichens across climatic and successional gradients. Canadian Journal of Forest Research 37(10): 1832-1845. https://doi.org/10.1139/X07-048

Gauslaa, Y. \& Solhaug, K. A. 1996. Differences in the susceptibility to light stress between epiphytic lichens of ancient and young boreal forest stands. Functional Ecology 10(3): 344-354.

Gauslaa, Y. \& Solhaug, K. A. 1999. High-light damage in air-dry thalli of the old forest lichen Lobaria pulmonaria - interactions of irradiance, exposure duration and high temperature. Journal of Experimental Botany 50: 697-705. https://doi. org/10.1093/jexbot/50.334.697

Gauslaa, Y., Solhaug, K. A. \& Longinotti, S. 2017. Functional traits prolonging photosynthetically active periods in epiphytic cephalolichens during desiccation. Environmental and Experimental Botany 141: 83-91. https://doi.org/10.1016/j. envexpbot.2017.07.005

Grimm, M., Grube, M., Schiefelbein, U., Zühlke, D., Bernhardt, J. \& Riedel, K. 2021. The lichens' microbiota, still a mystery? Frontiers in $\mathrm{Mi}$ crobiology 12: 623839. https://doi: 10.3389/ fmicb.2021.623839

Gu, W.-D., Kuusinen, M., Konttinen, T. \& Hanski, I. 2001. Spatial pattern in the occurrence of the lichen Lobaria pulmonaria in managed and virgin boreal forests. Ecography 24: 139-150. https:// doi.org/10.1034/j.1600-0587.2001.240204.x

Gustafsson, A. \& Milberg, P. 2008. Changes in the abundance of Lobaria pulmonaria in south-eastern Sweden from 1994 to 2007. Graphis Scripta 20: 44-51.

Gustafsson, L., Fiskesjö, A., Ingelög, T., Pettersson, B. $\&$ Thor, G. 1992. Factors of importance to some lichen species of deciduous broad-leaved woods in southern Sweden. Lichenologist 24: 255-266.

Hallingbäck, T. 1986. Lunglavarna, Lobaria, på reträtt i Sverige. Svensk Botanisk Tidskrift 80: 373-381.

Hallingbäck, T. \& Olsson, K. 1987. Lunglavens tillbakagång i Skåne. Svensk Botanisk Tidskrift 81: 103-108.

Hauck, M. \& Wirth, V. 2010. Preference of lichens for shady habitats is correlated with intolerance to high nitrogen levels. Lichenologist 42: 475-484. https://doi.org/10.1017/S0024282910000046 
Hawksworth, D. L. \& Rose, F. 1970. Qualitative scale for estimating sulphur dioxide air pollution in England and Wales using epiphytic lichens. $\mathrm{Na}$ ture 227: 145-148.

Hawksworth, D. L., Rose, F. \& Coppins, B. J. 1973. Changes in the lichen flora of England and Wales attributable to pollution of the air by sulphur dioxide. In: Ferry, W., Baddeley, M. S. \& Hawksworth, D. L. (eds). Air Pollution and Lichens. Pp. 330-367. University of London, Athlone Press, London.

Izydorek, I. 1987. Nowe stanowiska Lobaria pulmonaria (L.) Hoffm. (Lichenes) Na Pomorzu Zachodnim. Slupske Prace Matematyczno-Przyrodnicze 6: 119-12.

Johansson, P., Rydin, H. \& Thor, G. 2007. Tree age relationships with epiphytic lichen diversity and lichen life history traits on ash in southern Sweden. Ecoscience 14(1): 81-91. https:/ / doi.org/ 10 .2980/1195-6860(2007)14[81:TARWEL]2.0.CO;2

Jørgensen, P. M. \& Tønsberg, T. 2007. Lobariaceae. In: Ahti, T. et al. (eds). Nordic Lichen Flora Vol. 3, pp. 77-82. Museum of Evolution, Uppsala University, Uppsala.

Jüriado, I. \& Liira, J. 2009. Distribution and habitat ecology of the threatened forest lichen Lobaria pulmonaria in Estonia. Folia Cryptogamica Estonica 46: 55-65.

Jüriado, I. \& Liira, J. 2010. Threatened forest lichen Lobaria pulmonaria-its past, present and future in Estonia. Forestry Studies 53: 15-24. https:// doi.org/10.2478/v10132-011-0086-6

Jüriado, I., Liira, J., Csencsics, D., Widmer, I., Adolf, C., Kohv, K. \& Scheidegger, C. 2011. Dispersal ecology of the endangered woodland lichen $\mathrm{Lo}$ baria pulmonaria in managed hemiboreal forest landscape. Biodiversity and Conservation 20: 1803-1819. https://doi.org/10.1007/s10531011-0062-8

Jüridao, I. \& Paal, J. 2019. Epiphytic lichen synusiae and functional trait groups in boreo-nemoral deciduous forests are influenced by host tree and environmental factors. Nordic Journal of Botany 37(1): e01939. https://doi.org/10.1111/ njb.01939

Kalwij, J.-M., Wagner, H. H. \& Scheidegger, C. 2005. Effects of stand-level disturbances on the spatial distribution of a lichen indicator. Ecological Applications, 15(6): 2015-2024. https://doi. org/10.1890/04-1912

Krawiec, F. 1933. Materialy do flory porostow Pomorza [Contributions to the lichen flora of Pomerelia]. Acta Societatis Botanicorum Poloniae 10(1): 25-47.

Litterski, B. 1999. Pflanzengeographische und ökologische Bewertung der Flechtenflora MecklenburgVorpommerns. Dissertationes Botanicae 307: 1-391.

Neumann, P. \& Dolnik, C. 2018. Lobaria pulmonaria-die Echte Lungenflechte - und andere bemerkenswerte Flechtenfunde aus Schleswig-Holstein. Kieler Notizen zur Pflanzenkunde 43: 133-143.
Öckinger, E., Niklasson, M. \& Nilsson, S. G. 2005. Is local distribution of the epiphytic lichen Lobaria pulmonaria limited by dispersal capacity or habitat quality? Biodiversity and Conservation 14: 759-773. https://doi.org/10.1007/s10531004-4535-x

Öckinger, E. \& Nilsson, S. G. 2010. Local population extinction and vitality of an epiphytic lichen in fragmented old-growth forest. Ecology 91: 2100-2109. https://doi.org/10.1890/09-1421.1

Pentecost, A. 2020. The influence of sea water at a Lobaria site. British Lichen Society Bulletin 127: 21-23.

Phinney, N. H., Solhaug, K. A. \& Gauslaa, Y. 2019. Photobiont-dependent humidity threshold for chlorolichen photosystem II activation. Planta 250: 2023-2031. https://doi.org/10.1007/ s00425-019-03282-4

Pykäla, J. 2004. Effects of new forestry practices on rare epiphytic macrolichens. Conservation Biology 18(3): 831-838. https://doi.org/10.1111/j.15231739.2004.00210.x

Rose, F. 1992. Temperate forest management: its effect on bryophyte and lichen floras and habitats. In: Bates, J. W. \& Farmer, A. M. (eds). Bryophytes and Lichens in a Changing Environment, pp. 211-233. Clarendon Press, Oxford.

Rose, F. \& Purvis, O. W. 2009. Lobaria. In: Smith, C. W. et al. (eds). The Lichens of Great Britain and Ireland, pp. 560-562. The British Lichen Society, London.

Rostrup, E. 1864. Lollands vegetationsforhold. Videnskablige Meddelelser fra den naturhistoriske Forening $i$ Kjöbenhavn II, 6: 37-119.

Saxen, W. 1963. Zur Verbreitung der Lungenflechte im Lande Schleswig. Schriften des Naturwissenschaftlichen Vereins für Schleswig-Holstein 34: 84-88.

Schiefelbein, U., Schiefelbein, U. \& Thell, A. 2016. Lunglav Lobaria pulmonaria på stark tillbakagång i Skåne. Lavbulletinen 2-2016: 40-47.

Schiefelbein, U., Schiefelbein, U. \& Thell, A. 2017. Lunglav Lobaria pulmonaria i sydöstra Sverige. Lavbulletinen 2-2017: 56-65.

Schiefelbein, U. \& Thell, A. 2018. Current state of Lobaria pulmonaria in southernmost Sweden. Graphis Scripta 30(6): 94-104.

Seaward, M. R. D. \& Coppins, B. J. 2004. Lichens and hypertrophication. Bibliotheca Lichenologica 88: $561-572$.

Skagerberg, F. 2011. The effect of landscape structure on distribution and abundance of Lobaria pulmonaria. Exam work, Department of Biology, Gotland University, Visby.

Søchting, U. \& Christensen, S. N. 1989. Overvågning af laver i danske naturskove 1988. Overvågningsrapport. Miljøministeriet, Skov- og Naturstyrelsen, Hørsholm. 80 pp.

Thell, A. \& Schiefelbein, U. 2018. Lunglaven finns ännu i sydöstligaste Småland. Lavbulletinen 1-2018: 4-5. 
Urbanavichus, G. P. \& Andreev, M. P. 2010. A Checklist of the Lichen Flora of Russia. Nauka, St. Petersburg.

van Herk, C. M., Aptroot, A. \& van Dobben, H. F. 2002. Long-term monitoring in the Netherlands suggests that lichens respond to global warming. Lichenologist 34: 141-154.

Widmer, I., Dal Grande, F., Excoffier, L., Holderegger, R., Keller, C., Mikryukov, V. S. \& Scheidegger, C. 2012. European phylogeography of the epiphytic lichen fungus Lobaria pulmonaria and its green algal symbiont. Molecular Ecology 21: 5827-5844. https://doi.org/10.1111/mec. 12051

Wirth, V. 1968. Soziologie, Standortsökologie und Areal des Lobarion pulmonariae im Südschwarzwald. Botanische Jahrbücher 88: 317-365.
Wirth, V., Hauck, M., Brackel, W. v., Cezanne, R., de Bruyn, U., Dürhammer, O., Eichler, M., Gnüchtel, A., John, V., Litterski, B., Otte, V., Schiefelbein, U., Scholz, P., Schultz, M., Stordeur, R., Feuerer, T. \& Heinrich, D. 2011. Rote Liste und Artenverzeichnis der Flechten und flechtenbewohnenden Pilze Deutschlands. Naturschutz und Biologische Vielfalt 70(6): 7-122.

Wolseley, P. \& James, P. 2000. Factors affecting changes in species of Lobaria in sites across Britain. Forest and Snow Landscape Research 75(3): 319-338. 


\section{APPENDIX 1}

\section{List of localities of Lobaria pulmonaria studied between 2015 and 2018}

(Number of studied trees at the localities are in brackets. These numbers represent the number of trees on which L. pulmonaria was found.)

Denmark, North Jutland region, Rebild, Rold Skov, Torstedlund Skov, Lillevangvejen, c. $2,3 \mathrm{~km}$ SSW of Årestrup, $56^{\circ} 47^{\prime} \mathrm{N}, 09^{\circ} 43^{\prime} \mathrm{E}$, alt. c. $65 \mathrm{~m}$, narrow strip of old growth, species-poor acidi beech forest between coniferous plantations, 29 May 2016 (3)

Denmark, North Jutland region, Rebild, Rold Skov, Torstedlund Skov, Langemose, c. 1,8 $\mathrm{km}$ SSE of Årestrup, $56^{\circ} 48^{\prime} \mathrm{N}, 09^{\circ} 45^{\prime} \mathrm{E}$, alt. c. $80 \mathrm{~m}$, old growth, species-poor acidic beech forest surrounded by clear cuttings and spruce forests and single beech trees along peatland, 29 May 2016 (2)

Denmark, North Jutland region, Mariagerfjord, Rold Skov, RoldVesterskov, Roldkilden, c. $0,25 \mathrm{~km} \mathrm{~N}$ of the road No. 535, 56 $46^{\prime} \mathrm{N}$, $09^{\circ} 47^{\prime} \mathrm{E}$, alt. c. 55-65 m, old growth, speciespoor acidic beech forest on $\mathrm{N}$-exposed slope, 29 May 2016 (3)

Denmark, North Jutland region, Mariagerfjord, Rold Skov, Kærbjerg Skov, N of Møldrupvej, $56^{\circ} 47^{\prime} \mathrm{N}, 09^{\circ} 54^{\prime} \mathrm{E}$, alt. c. $45-55 \mathrm{~m}$, old growth, species-poor acidic beech forest on a NW- to N-exposed slope, 29 May 2016 (7)

Denmark, North Jutland region, Rebild, Rold Skov, Kærbjerg Skov, Aspvej, E of the cross$\mathrm{road}, 56^{\circ} 48^{\prime} \mathrm{N}, 09^{\circ} 54^{\prime} \mathrm{E}$, alt. c. $45 \mathrm{~m}$, single beech at a roadside surrounded by larch forests, 29 May 2016 (1)

Denmark, North Jutland region, Rebild, Rold Skov, Store Økssø, Tvillingskov, E of the railway, $56^{\circ} 48^{\prime} \mathrm{N}, 09^{\circ} 52^{\prime} \mathrm{E}$, alt. c. $75-85 \mathrm{~m}$, old growth, species-poor acidic beech forest, 29 May 2016 (4)

Denmark, Central Jutland region, Viborg, Hald Sø, Inderø Skov, north western edge of the peninsula, $56^{\circ} 22-23^{\prime} \mathrm{N}, 09^{\circ} 20^{\prime} \mathrm{E}$, alt. c. 15-25 m, old growth, species-poor acidic beech forest at lake side, 30 May 2016 (10)

Denmark, Central Jutland region, Viborg, Troldeslugten, c. 0,6 km W of Niels Bugges Kro, $56^{\circ} 23^{\prime} \mathrm{N}, 09^{\circ} 19-20^{\prime} \mathrm{E}$, alt. c. $40-45 \mathrm{~m}$, old growth, species-poor oak forest at edge of a deeply incised valley, 30 May 2016 (4)

Denmark, Central Jutland region, Skive, Kås Skov, c. $1,9 \mathrm{~km} \mathrm{~N}$ of Kås Hovedgård, $56^{\circ} 23^{\prime} \mathrm{N}, 09^{\circ} 19-20^{\prime} \mathrm{E}$, alt. c. $25-30 \mathrm{~m}$, old growth, species-poor oak forest on sandy plain, 30 May 2016 (7)

Denmark, North Jutland region, Rebild, Rold Skov, Buderupholm, c. 1,4 km W of Skørping, $56^{\circ} 51^{\prime} \mathrm{N}, 09^{\circ} 52^{\prime} \mathrm{E}$, alt. c. $70 \mathrm{~m}$, old growth, mesophytic species-rich beech forest, 31 May 2016 (1)

Denmark, Central Jutland region, Ikast-Brande, Stenholt N, c. $1,2 \mathrm{~km} \mathrm{~N}$ of Klosterlund $\mathrm{Mu}-$ seum, $56^{\circ} 11^{\prime} \mathrm{N}, 09^{\circ} 21^{\prime} \mathrm{E}$, alt. c. $110 \mathrm{~m}$, old growth, species-poor oak forest, 31 May $2016(8)$

Denmark, Central Jutland region, Ikast-Brande, Stenholt S, c. $0,8 \mathrm{~km}$ NNW of Klosterlund Museum, $56^{\circ} 11^{\prime} \mathrm{N}, 09^{\circ} 20^{\prime} \mathrm{E}$, alt. c. $110 \mathrm{~m}$, old growth, species-poor oak forest, 31 May $2016(7)$

Denmark, Central Jutland region, Silkeborg, Vesterskov, c. $1,3 \mathrm{~km} \mathrm{~S}$ of Funderholme, $56^{\circ} 08^{\prime} \mathrm{N}, 09^{\circ} 30^{\prime} \mathrm{E}$, alt. c. $55 \mathrm{~m}$, old growth, species-poor acidic beech forest (with Ilex), 31 May 2016 (3)

Denmark, Central Jutland region, Silkeborg, Virklund, Avns $\varnothing$, c. $0,7 \mathrm{~km} \mathrm{E}$ of the transit station Horsensvej/Uglesøvej, $56^{\circ} 08^{\prime} \mathrm{N}$, $09^{\circ} 34^{\prime} \mathrm{E}$, alt. c. $35 \mathrm{~m}$, old beeches at lake side near spruce plantation, 31 May 2016 (2)

Denmark, Central Jutland region, Silkeborg, Velling, Velling Skov E, c. 1,3 km SW of the transit station Vellingvej/Lystruphavevej, $56^{\circ} 02^{\prime} \mathrm{N}, 09^{\circ} 31^{\prime} \mathrm{E}$, alt. c. $90 \mathrm{~m}$, old growth, species-poor acidic beech forest (with Ilex), 1 June 2016 (3)

Denmark, Central Jutland region, Silkeborg, Velling, Velling Skov W, c. 1,9 km SE of the transit station Vellingvej/Lystruphavevej, $56^{\circ} 02^{\prime} \mathrm{N}, 09^{\circ} 29^{\prime} \mathrm{E}$, alt. c. 95-110 m, old growth, species-poor acidic beech forest (with Ilex), 1 June 2016 (4)

Denmark, Central Jutland region, Silkeborg, Addit Skov, c. $0,35 \mathrm{~km}$ SE of castle Løndal, $56^{\circ} 03^{\prime} \mathrm{N}, 09^{\circ} 35^{\prime} \mathrm{E}$, alt. c. $75 \mathrm{~m}$, small old growth, species-poor acidic beech forest (with Ilex) surrounded by spruce forest and grassland, 1 June 2016 (1)

Denmark, Central Jutland region, Silkeborg, Gjessø, Gjessø Skov, Kjellerup Dal, c. 1 
$\mathrm{km}$ WSW of the transit station Egebakken, $56^{\circ} 07^{\prime} \mathrm{N}, 09^{\circ} 30^{\prime} \mathrm{E}$, alt. c. $60 \mathrm{~m}$, old growth, species-poor acidic beech forest in ravine, 1 June 2016 (3)

Denmark, Central Jutland region, Silkeborg, Virklund, Knagerne, c. 1,1 km W of the transit station Virklund Gunilshøjvej/ Rundkørsel, $56^{\circ} 08^{\prime} \mathrm{N}, 09^{\circ} 32^{\prime} \mathrm{E}$, alt. c. $85 \mathrm{~m}$, old growth, species-poor acidic beech forest (with Ilex), 1 June 2016 (1)

Denmark Central Jutland region, Silkeborg, Frederik den syvendes høj, c. 1,7 km S of Funderholme, $56^{\circ} 08^{\prime} \mathrm{N}, 09^{\circ} 30^{\prime} \mathrm{E}$, alt. c. 100 $\mathrm{m}$, old growth, species-poor acidic beech forest (with Ilex), 1 June 2016 (1)

Denmark, Capital region, Hillerød, c. $6 \mathrm{~km} \mathrm{NE}$ of Hillerød, Nødebo Holt, $55^{\circ} 58^{\prime} \mathrm{N}, 12^{\circ} 21^{\prime} \mathrm{E}$, alt. c. $15 \mathrm{~m}$, species-poor acidic beech forest at lake side, leg. U. Søchting, 25 Dec. 2015 (1)

Denmark, Central Jutland region, Viborg, Lindum Skov, c. $10 \mathrm{~km}$ SW of Hobro, $56^{\circ} 35^{\prime} \mathrm{N}$, $09^{\circ} 40^{\prime} \mathrm{E}$, alt. c. $15 \mathrm{~m}$, small stand (25 trees) of beeches on acidic soil surrounded by small lake, spruce and larch plantations, 4 June 2016 (2)

Denmark, Central Jutland region, Viborg, Sødal Egekrat, c. $8 \mathrm{~km} \mathrm{NE}$ of Viborg, $56^{\circ} 30^{\prime} \mathrm{N}$, $09^{\circ} 31^{\prime} \mathrm{E}$, alt. c. $35 \mathrm{~m}$, old growth, speciespoor oak forest mixed with beech and hazel, 6 July 2016 (1)

Denmark, Central Jutland region, Holstebro, Troldtoft Egekrat, Stråsø Plantage, c. 13 km SW of Holstebro, $56^{\circ} 14^{\prime} \mathrm{N}, 08^{\circ} 31^{\prime} \mathrm{E}$, alt. c. 50 $\mathrm{m}$, species-poor oak forest mixed with few Populus tremula, 15 July 2016 (1)

Denmark, North Jutland region, Mariagerfjord, Tofte Bøge, Tofte Skov, Lille Vildmose, c. 20 $\mathrm{km}$ SE of Aalborg, $56^{\circ} 50^{\prime} \mathrm{N}, 10^{\circ} 11^{\prime} \mathrm{E}$, alt. c. 15-25, old growth, species-poor acidic beech forest towards raised bog, 28 July 2016 (3)

Denmark, North Jutland region, Mariagerfjord, Sønderup Ådal, Skivum Nørrekrat, c. 1,5 $\mathrm{km}$ E of Vegger, $56^{\circ} 53^{\prime} \mathrm{N}, 09^{\circ} 36^{\prime} \mathrm{E}$, alt. c. 25 $\mathrm{m}$, species-poor oak forest with beech and Populus tremula, 11 Aug. 2016 (1)

Denmark, North Jutland region, Mariagerfjord, Hellum Skov, Rold Skov, c. $1 \mathrm{~km}$ E of parking place of Madum Sø, $56^{\circ} 47^{\prime} \mathrm{N}, 10^{\circ} 57^{\prime} \mathrm{E}$, alt. c. $70 \mathrm{~m}$, old growth, species-poor acidic beech forest, 23 Aug. 2016 (3)

Denmark, North Jutland region, Mariagerfjord, Knebel Bakker, Rold Skov, c. 1,5 km ESE of Skørping station, $56^{\circ} 49^{\prime} \mathrm{N}, 09^{\circ} 54^{\prime} \mathrm{E}$, alt. c.
$60 \mathrm{~m}$, old growth, species-poor acidic beech forest and forest margin, 25 Aug. 2016 (3)

Germany, Schleswig-Holstein, Jörl, Pobüller Bauernholz, $54^{\circ} 37^{\prime} \mathrm{N}, 09^{\circ} 15^{\prime} \mathrm{E}$, alt. c. $20 \mathrm{~m}$, mixed oak-hornbeam forest, 28 Nov. 2015 (1)

Germany, Mecklenburg-Vorpommern, Born, Darß Peninsula, beech forest c. 3,5 km N of the youth hostel Born-Ibenhorst, $54^{\circ} 26^{\prime} \mathrm{N}$, $12^{\circ} 29^{\prime} \mathrm{E}$, alt. c. $5 \mathrm{~m}$, species-poor acidic beech forest, 11 Sept. 2015 (4)

Germany, Mecklenburg-Vorpommern, Born, Darß Peninsula, beech forest c. $5,9 \mathrm{~km} \mathrm{~N}$ of the youth hostel Born-Ibenhorst, $54^{\circ} 27^{\prime} \mathrm{N}$, $12^{\circ} 23^{\prime} \mathrm{E}$, alt. c. $5 \mathrm{~m}$, species-poor acidic beech forest, 12 Sept. 2015 (1)

Germany, Schleswig-Holstein, Schleswig-Flensburg, Handwitt, Handewitter Forst, 54 ${ }^{\circ} 45^{\prime} \mathrm{N}$, $09^{\circ} 19^{\prime} \mathrm{E}$, alt. c. $40 \mathrm{~m}$, acidophilous oak forest, 16 Febr. 2018 (2)

Germany, Mecklenburg-Votpommern, Vorpommern-Rügen, Rügen Island, Stubnitz, $\mathrm{S}$ of Stubbenkammer, $54^{\circ} 34^{\prime} \mathrm{N}, 13^{\circ} 40^{\circ} \mathrm{E}$, alt. c. 100 m, calcareous beech forest, 29 Nov. 2018 (1)

Poland, Kujawy-Pomerania, Świecie, Tuchola forest, c. 2,5 km NE of Stara Rzeka, 5339'N, $18^{\circ} 19^{\prime} \mathrm{E}$, alt. c. $90 \mathrm{~m}$, Tilio-Acerion forests on non-stony soils, 30 July 2017 (2)

Poland, Pomerania, Łupawa, c. 1,7 km ESE Łupawa, forest section $76 \mathrm{c}, 54^{\circ} 25^{\prime} \mathrm{N}, 17^{\circ} 26^{\prime} \mathrm{E}$, alt. c. $85 \mathrm{~m}$, species-poor oak forest, 10 Nov. 2017(1)

Pomerania, Wejherowo, c. 1,5 km ESE Pińskie, forest section $74 \mathrm{~g}, 54^{\circ} 32{ }^{\prime} \mathrm{N}, 18^{\circ} 20^{\prime} \mathrm{E}$, alt. c. $125 \mathrm{~m}$, species-poor acidic beech forest, 10 Nov. 2017 (1)

Pomerania, Bytów, Gostkowo, Gołębia Góra, c. 0,4 km NE of the parking place Gołębia Góra, forest section $396 \mathrm{a}, 54^{\circ} 15^{\prime} \mathrm{N}, 17^{\circ} 29^{\prime} \mathrm{E}$, alt. c. $95 \mathrm{~m}$, species-poor acidic beech forest, 11. Nov. 2017 (1)

Pomerania, Bytów, Borzytuchom, c. $3,0 \mathrm{~km} \mathrm{~W}$ of Jutrzenko, forest section $227 \mathrm{a}, 54^{\circ} 12^{\prime} \mathrm{N}$, $17^{\circ} 16^{\prime} \mathrm{E}$, alt. c. $75 \mathrm{~m}$, species-poor oak forest, 11. Nov. 2017 (1)

Pomerania, Skarszów, c. 1,6 km E of Dębnica Kaszubska, forest section $162 \mathrm{a}, 54^{\circ} 22^{\prime} \mathrm{N}$, $17^{\circ} 13^{\prime} \mathrm{E}$, species-poor acidic beech forest, 12. Nov. 2017 (1)

Sweden, Skåne, Simrishamn, Norr om Måsalycke, c. $0,6 \mathrm{~km}$ S of St. Olof, $55^{\circ} 38^{\prime} \mathrm{N}, 1^{\circ} 08^{\prime} \mathrm{E}$, alt. c. $125 \mathrm{~m}$, old growth, species-rich, eutrophic beech forest, 30 June 2016 (1) 
Sweden, Skåne, Hässleholm, Göingeholm, c. $0,7 \mathrm{~km}$ SSE of Göingeholms Gård, $55^{\circ} 57^{\prime} \mathrm{N}$, $13^{\circ} 42^{\prime} \mathrm{E}$, alt. c. $125 \mathrm{~m}$, old growth, speciespoor acidic beech forest with oaks, 01 July 2016 (1)

Sweden, Skåne, Klippan, Färingtofta, c. 2,8 $\mathrm{km}$ SSE of Färingtofta, $56^{\circ} 01^{\prime} \mathrm{N}, 13^{\circ} 23^{\prime} \mathrm{E}$, alt. c. $55 \mathrm{~m}$, old growth, mixed mixed oakhornbeam forest, 02 July 2016 (1)

Sweden, Skåne, Klippan, Skäralid, Söderåsen National Park, c. 1,7 km WSW of the "Naturum Söderåsen”, $56^{\circ} 01^{\prime} \mathrm{N}, 13^{\circ} 13^{\prime} \mathrm{E}$, alt. c. $110 \mathrm{~m}$, old growth, species-rich, eutrophic beech forest on $\mathrm{N}$-(NW-) exposed steep slope, 03 July 2016 (3)

Sweden, Skåne, Klippan, Skäralid, Söderåsen National Park, c. 4,2 km SW of the "Naturum Söderåsen”, $56^{\circ} 01^{\prime} \mathrm{N}, 13^{\circ} 12^{\prime} \mathrm{E}$, alt. c. $110 \mathrm{~m}$, damaged Tilio-Acerion forest, on $\mathrm{N}$-exposed steep, rocky slope, 03 July 2016 (1)

Sweden, Skåne, Höganäs, Kullen, N of the golf course, $56^{\circ} 18^{\prime} \mathrm{N}, 12^{\circ} 28^{\prime} \mathrm{E}$, alt. c. $30 \mathrm{~m}$, TilioAcerion forest on $\mathrm{N}$-exposed steep, rocky slope, 04 July 2016 (2)

Sweden, Skåne, Hallaröd, Allarpsbjär, $56^{\circ} 00^{\prime} \mathrm{N}$, $13^{\circ} 25^{\prime} \mathrm{E}$ (all specimens around this point, alt. c. $100 \mathrm{~m}$, Tilio-Acerion forest on rocky ground, 27 July 2016 (4)

Sweden, Blekinge, Sölvesborg, forest N of the E 22 , SW of the exit to Gammalstorp, $56^{\circ} 04^{\prime} \mathrm{N}$, $14^{\circ} 35^{\prime} \mathrm{E}$, alt. c. $20-50 \mathrm{~m}$, species-poor acidic beech forest, 11 May 2017 (3)

Sweden, Blekinge, Sölvesborg, forest S of Leingarydsvägen, E of Sondre Vång, $56^{\circ} 08^{\prime} \mathrm{N}$, $14^{\circ} 32^{\prime} \mathrm{E}$, alt. c. $50 \mathrm{~m}$, species-poor acidic beech forest, 11 May 2017 (1)

Sweden, Blekinge, Sölvesborg, forest S of Leingarydsvägen, NE of Finkelman, 56 $08^{\prime} \mathrm{N}$, $14^{\circ} 33^{\prime} \mathrm{E}$, alt. c. $80 \mathrm{~m}$, species-poor acidic beech forest, 11 May 2017 (1)

Sweden, Blekinge, Sölvesborg, forest E of Leingarydsvägen, $\mathrm{E}$ of crossover $\mathrm{NE}$ of Leingarydsvägen/Hagstads byaväg, Täppet, $56^{\circ} 08^{\prime} \mathrm{N}$, $14^{\circ} 34^{\prime} \mathrm{E}$, alt. c. $80 \mathrm{~m}$, species-poor acidic beech forest, 11 May 2017 (1)

Sweden, Blekinge, Karlshamn, Stensnäs, peninsula $\mathrm{E}$ of Pukavik, $56^{\circ} 09^{\prime} \mathrm{N}, 14^{\circ} 42^{\prime} \mathrm{E}$, alt. c. 0-15 m, species-rich, eutrophic beech forest, 12 May 2017 (3)
Sweden, Blekinge, Karlshamn, Stensnäs, peninsula E of Pukavik, $56^{\circ} 10^{\prime} \mathrm{N}, 14^{\circ} 42^{\prime} \mathrm{E}$, alt. c. $5 \mathrm{~m}$, species-poor acidic beech forest, 12 May 2017 (1)

Sweden, Blekinge, Ronneby, Bökevik, peninsula $\mathrm{W}$ of Trolleboda, $56^{\circ} 09^{\prime} \mathrm{N}, 15^{\circ} 10^{\prime} \mathrm{E}$, alt. c. $20 \mathrm{~m}$, species-poor acidic beech forest, 12 May 2017 (1)

Sweden, Blekinge, Ronneby, Kjättorp, SW Ronneby, W Kjättorp, $56^{\circ} 14^{\prime} \mathrm{N}, 15^{\circ} 14^{\prime} \mathrm{E}$, alt. c. $40 \mathrm{~m}$, Tilio-Acerion forest on rocky ground, 12 May 2017 (2)

Sweden, Blekinge, Ronneby, Näsudden, Bräkne-Hoby, peninsula in the lake Nässjön, $56^{\circ} 14^{\prime} \mathrm{N}, 15^{\circ} 12^{\prime} \mathrm{E}$, alt. c. $30 \mathrm{~m}$, free-standing tree on pasture, 12 May 2017 (1)

Sweden, Blekinge, Ronneby, Näs, Bräkne-Hoby, $56^{\circ} 14^{\prime} \mathrm{N}, 15^{\circ} 12^{\prime} \mathrm{E}$, alt. c. $30 \mathrm{~m}$, mixed oak-hornbeam forest, 12 May 2017 (3)

Sweden, Blekinge, Ronneby, Listerby, Tromtö, Ringholmen, $56^{\circ} 09^{\prime} \mathrm{N}, 15^{\circ} 30^{\prime} \mathrm{E}$, alt. c. $5 \mathrm{~m}$, mixed oak-hornbeam forest, 13 May 2017 (1)

Sweden, Blekinge, Ronneby, Listerby, Hjortsberga, Johannishus åsar, $56^{\circ} 09^{\prime} \mathrm{N}, 15^{\circ} 29^{\prime} \mathrm{E}$, alt. c. $40 \mathrm{~m}$, free-standing tree on pasture, 13 May 2017 (1)

Sweden, Blekinge, Karlskrona, Nättraby, Skallahult, $56^{\circ} 14^{\prime} \mathrm{N}, 15^{\circ} 30^{\prime} \mathrm{E}$, alt. c. $40 \mathrm{~m}$, Tilio-Acerion forest on rocky ground, 13 May 2017 (4)

Sweden, Skåne, Kristianstad, Vånga, Orehagen, $56^{\circ} 09^{\prime} \mathrm{N}, 14^{\circ} 25^{\prime} \mathrm{E}$, alt. c. $55 \mathrm{~m}$, species-poor, Tilio-Acerion forest on rocky ground, 14 May 2017 (2)

Sweden, Skåne, Bromölla, Näsum, between Vånga and Näsum, $56^{\circ} 10^{\prime} \mathrm{N}, 14^{\circ} 26^{\prime} \mathrm{E}$, alt. c. $150 \mathrm{~m}$, species-poor acidic beech forest, 14 May 2017 (2)

Sweden, Skåne, Kristianstad, Nosaby, Österslöv, $56^{\circ} 08^{\prime} \mathrm{N}, 14^{\circ} 14^{\prime} \mathrm{E}$, alt. c. $50 \mathrm{~m}$, species-poor acidic beech forest, 15 May 2017 (1)

Sweden, Skåne, Hässleholm, Västra Torup, W Håkantorp, Håkantorpshall, 56 $07^{\circ} \mathrm{N}$, $13^{\circ} 28^{\prime} \mathrm{E}$, alt. c. $130 \mathrm{~m}$, species-poor acidic beech forest, 15 May 2017 (1)

Sweden, Småland, Mortorp, forest between Mortorp and Väntorp, $56^{\circ} 35^{\prime} \mathrm{N}, 16^{\circ} 06^{\prime} \mathrm{E}$, alt. c. $25 \mathrm{~m}$, species-poor acidic beech forest, 15 April 2018 (1) 